\title{
Management of Tumoral Calcinosis-A Rare Case Report
}

\author{
Dr.ShivalingappaJArakeri", Dr. Anju G. Das**, Dr.SyedaAther Fathima**, Dr. Mohasin \\ Kadegaon $^{* *}$, Dr.Geethanjali Hiremath ${ }^{* *}$
}

\begin{abstract}
*Associate Professor \& HOD, Department of Shalya Tantra, Taranath Government Ayurvedic Medical College, Ballari (Karnataka, India) ***PG Scholar, Department of Shalya Tantra, Taranath Government Ayurvedic Medical College, Ballari (Karnataka, India)

${ }^{* *}$ Principal, Taranath Government Ayurvedic Medical College, Ballari (Karnataka, India)

**Assistant Professor Department of Shalya Tantra, Taranath Government Ayurvedic Medical College, Ballari

**A Assistant Professor Department of Shalya Tantra, Taranath Government Ayurvedic Medical College, Ballari
\end{abstract}

DOI: 10.29322/IJSRP.10.06.2020.p10296

http://dx.doi.org/10.29322/IJSRP.10.06.2020.p10296

\begin{abstract}
Tumoral Calcinosis is an extremely rare benign condition frequently misdiagnosed, of unknown origin. It presents as calcified tumors, usually around the hips and buttocks, shoulder, elbow in muscle and subcutaneous tissue. Growth of such lesions is mostly slow and progressive in nature. Sometimes, ulceration of the overlying skin occurs with superadded secondary infection. This condition may be familial and is seen most often in black Africans.Approximately 1\% prevalence of periarticular masses seen in secondary Tumoral Calcinosis. A 30 years old male patient came to OPD at Taranath Govt. Ayurveda Medical College, Ballari on 04 April 2019 presented with complaints of palpable hard swelling on natal cleft with pain and itchingfor 2 months.Surgical excision was performed and recurrence was not observed in follow up period.
\end{abstract}

Index Terms- Tumoral Calcinosis, gluteal region, Surgical excision

\section{INTRODUCTION}

$\mathrm{T}$ umoral Calcinosis is considered as an independent disease, in which there is calcium deposition in the soft tissue in periarticular regions. It is occurring without sex predilection and lesions primarily proliferate during first 2 decades of life $^{1}$. A genetical disorder, recurrent soft tissue microtrauma or terminal renal failure are blamed to cause Tumoral Calcinosis². All these causes may lead to localized or generalized disturbances of calcium-phosphate metabolism which in turn causes Tumoral Calcinosis. Approximately $1 \%$ prevalence of periarticular masses seen in secondary Tumoral Calcinosis. Tumoral Calcinosis can be subdivided etiologically into primary type with no associated diseases and secondary type that follows other disorders like hyperparathyroidism, malignancy, sarcoidosis, scleroderma, prolonged hemodialysis ${ }^{3}$.

\section{CASE REPORT}

A 30-year-old male patient visited to Out Patient Department (OPD) at Taranath Govt. Ayurveda College,Ballari, Karnataka on 04April 2019 presented with complaints of palpable hard swelling on natal cleft with pain and itching for 2 months. No pus discharge was there. There was no history of trauma or any other significant medical illness. Patient had no history of Diabetes Mellitus, Hypertension or Thyroid problems and was not suffering from any other skin ailment or bleeding disorders. He was not under any medication for any ailments.

\section{Personal History:}

Bowel: Regular

Appetite: Good

Micturition: Normal

Sleep: Disturbed due to pain

\section{Family History:}

Nothing significant

\section{Physical examination:}

Patient was moderately built

B.P: $130 / 80 \mathrm{~mm}$ of $\mathrm{Hg}$

P.R: $74 / \mathrm{min}$

Systemic Examination:

CVS: S1, S2 heard. No added sound

CNS: NAD

RS: NAD

GIT: NAD

\section{Specific Examination:}

Inspection: A swelling of $3 * 3 \mathrm{~cm}$ was seen on natal cleft with absence of pus discharge. Inflammatory signs notelicited.

Palpation: The swelling was tender, hardandfixed.

\section{Investigation:}

Routine blood was normal, HIV test was negative.

FNAC report was suggestive of Tumoral Calcinosis. 


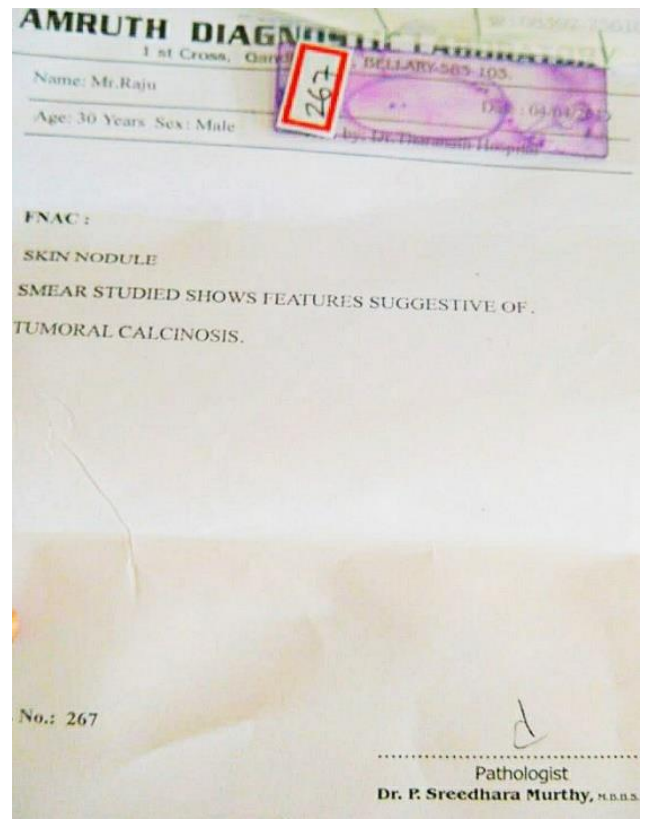

Figure 1: FNAC report

Clinical Diagnosis: Tumoral Calcinosis

Management:Treatment of choice was complete excision of mass.

Pre- Operative notes:

- Informed and written consent was taken

- Part preparation

- Inj. Xylocaine $(0.2 \mathrm{ml})$ - test dose

Operative notes:

- Inj. TT(0.5 ml) IM

Under all aseptic precautions,patient shifted to OT and put under prone position. The operative site was painted and draped.Inj. Xylocaine with adrenaline $2 \%-5 \mathrm{ml}$ infiltrated locally. The mass was held with Alli's Tissue forceps and excised with the help of cautery. Apamargaksharataila was applied. The wound was properly cleaned with betadine anddressing done with JatyadiTaila. Hemostasismaintained throughout the procedure. Patient withstood the procedure well. After stabilizing vitals patient shifted to the ward.

Post- Operative notes:

- Antibiotics and analgesics for 5 days

- Cleaning and dressing

- Oral medications: Sapthavimshatikaguggulu(TI D,After food), Gandhakarasayana (TID, After food) for 10 days.

- Sitz bath

Patient was reviewed 10 days later. Signs of healing of post- operative wound was observed. No recurrence was observed during follow up period.

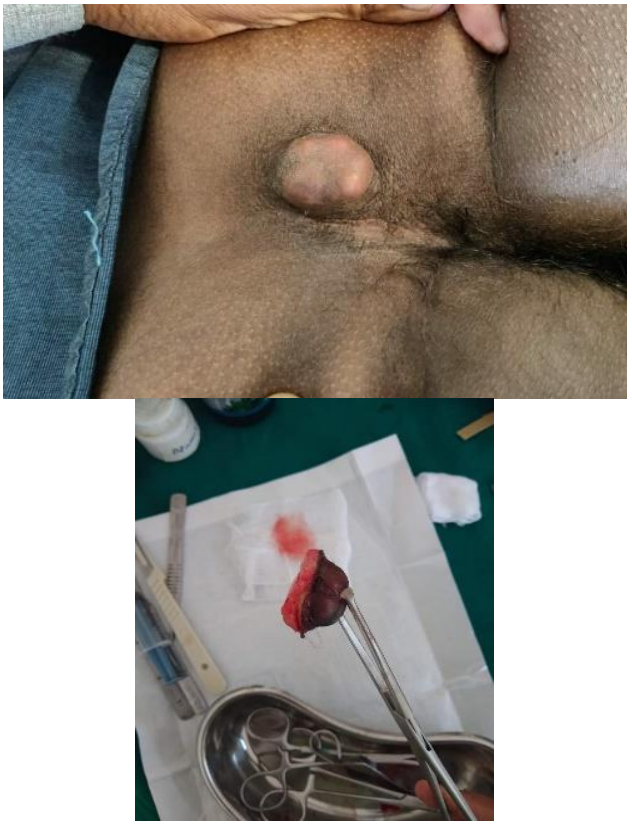

Figure 2: Before treatment

Figure 3: Excised mass

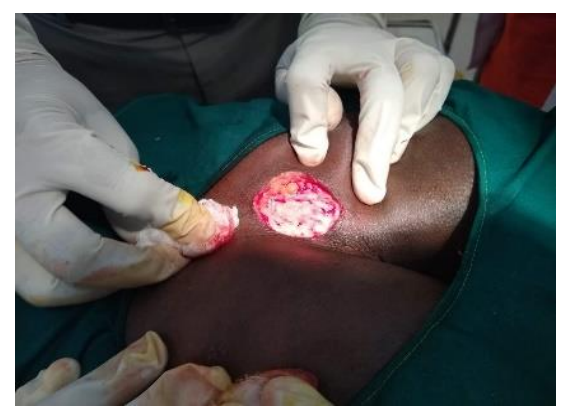

Figure 4: After excision

\section{DISCUSSION}

Tumoral Calcinosis is a phosphocalcic metabolism anomaly, particularly among younger age groups and characterized by the presence of calcified masses in the juxta articular regions ${ }^{4}$.Genetic disorders, recurrent soft tissue trauma, renal failure, hypervitaminosis D are among the main causes of Tumoral Calcinosis ${ }^{3}$.

Patients usually present with multiple or solitary swellings related to the joints, discomfort, pain and joint movement limitation most commonly affecting the hip, elbow, shoulder, foot, wrist.

Diagnosis of Tumoral Calcinosis is mainly based on imaging modalities. Plain radiographs show the typical appearance of amorphous, multilobulated and cystic calcifications in a periarticular location. CT helps in determining the extension and relations of individual lesions. It usually shows cystic loculi with fluid levels caused by calcium layering giving rise to "the sedimentation sign". MRI shows in-homogenous high signal intensity on T2-weighted sequences with two patterns frequently observed; diffuse lower signal intensity pattern, nodular pattern with alternating areas of high signal intensity and signal void. 
Ultrasonography can also be of value in detecting loculated fluid collections ${ }^{5}$.

\section{CONCLUSION}

Tumoral Calcinosis is a rare case which is typically seen in peri-articular soft tissues exposed to repetitive trauma or prolonged pressure such as hips, elbows and shoulders. This 30year-old male patient, with no family history and with no other biochemical, radiological abnormality was treated successfully with wide local excision with no recurrence.

\section{REFERENCES}

[1] Kathryn M. Olsen, Felix S. Chew, Tumoral Calcinosis: Pearls,Polemics and Alternative Possibilities, Radiographics[Internet]. 2006[May1];Vol.26,no.3:https://doi.org/10.1148/rg.263055099

[2] E Mayr, W Braun, M Rudzki, A Ruter, Tumoral Calcinosis- An Independent Disease,ZentralbrChir[Internet].1996;121(6):496-502. German. PMID: 8767339

[3] Warren C Hammert, Leroy R Lindsay, Tumoral Calcinosis-Or Is It? A Case Report and Review[Internet].2009[June];4(2):119-122. PMID: 18807094.DOI: 10.1007/s11552-008-9132-0

[4] Shoukat Y M, Malik E F, Al Rashid M, Cannon S R, Large Tumoral Calcinosis in the Gluteal Region: A Case Report, OrtopTraumatolRehabil.[Internet]2013;15950:495-499. doi:10.5604/15093492.1084363.

[5] Li-An Lai, MD, Ming-Yen Hsiaso, Chueh-Hung Wu, MD, TyngGueyWang,MD, LeventOzcakar, MD, Big Gain, No Pain: Tumoral Calcinosis, The American Journal of Medicine[Internet],2018[January 01,2018]; Volume 131, Issue 1, P45-47, https://doi.org/10.1016/j.amjmed.2017.09.003

\section{AUTHORS}

First author- Dr. Shivalingappa J Arakeri, M.S (Ayu) Associate Professor \& HOD, Department of Shalya Tantra, Taranath Government Ayurvedic Medical College, Ballari (Karnataka, India), shivu.doc.29@gmail.com.

Second author- Dr. Anju G. Das, PG Scholar, Department of Shalya Tantra, Taranath Government Ayurvedic Medical College, Ballari (Karnataka, India), anjugracydas15@gmail.com. Third author- Dr. SyedaAther Fathima, M.S(Ayu) Principal, Taranath Government Ayurvedic Medical College, Ballari (Karnataka, India), principaltgamc@gmail.com.

Fourth author- Dr. Mohasin Kadegaon, M.S(Ayu) Assistant Professor Department of Shalya Tantra, Taranath Government Ayurvedic Medical College, Ballari (Karnataka, India), drmohsinkadegaon@gmail.com.

Fifth author- Dr. Geethanjali Hiremath, M.S(Ayu) Assistant Professor Department of Shalya Tantra, Taranath Government Ayurvedic Medical College, Ballari (Karnataka, India), sanjalihiremath@gmail.com.

Corresponding Author: Dr. Shivalingappa J Arakeri, M.S(Ayu) Associate Professor \& HOD, Department of Shalya Tantra, Taranath Government Ayurvedic Medical College, Ballari (Karnataka, India), shivu.doc.29@gmail.com, contact no: 9845894052 